\title{
A Study of Ewenki Music Culture*
}

\author{
Weibo Dang \\ School of Music \\ Heihe University \\ Heihe, China 164300
}

\author{
Rui Zhang \\ School of Music \\ Heihe University \\ Heihe, China 164300
}

\begin{abstract}
The Ewenki nationality is one of the minorities with a small population in China. The statistical population in the sixth China population census is 30,875 . The ancestors of Ewenki are the forest hunters living in the Khingan Mountains. They are currently mainly located in the counties, districts, and townships of the Inner Mongolia Autonomous Region and Heilongjiang Province, and live a farming settlement life. The Ewenki nationality is a special nation with only ethnic languages and no ethnic language. Now it mainly uses Chinese, and also uses Mongolian and Ewenki languages. In the long history and rich traditional culture of the Ewenki people, the most prominent one is the music culture. Ewenki music culture is an important part of the music culture of the Chinese nation, a valuable asset of the Ewenki people and even the Chinese nation, as well as a true portrayal of the Ewenki hunting to nomadic life.
\end{abstract}

Keywords-Ewenki; music; folk songs; musical instruments

\section{INTRODUCTION}

The Ewenki music culture is the essence of its national culture. The Ewenki ethnic group has rich cultural resources, especially music and cultural resources. The development of music art is never single, and it is formed, developed and enriched in the process of continuously absorbing, learning and creating national culture and has distinctive ethnic music and art features. Due to space limitations, this paper mainly combed from the Ewenki folk songs and musical instruments according to the classification of music culture.

\section{ClassificATION OF THE THEME OF THE EWENKI FOLK SONGS}

According to the theme, the Ewenki folk songs can be divided into five categories: labor songs, homesick folk songs, love and wedding folk songs, historical folk songs, and divine songs. Some of them are general folk songs, and some are divine songs with the core of shamanic belief. This classification method reflects the portrayal of story and wisdom of the Ewenki folk songs that were produced by the Ewenki people for generations.

\section{A. Labor Songs}

Songs with this type of theme are the songs that describe

*This dissertation is a phased achievement of the special project of the Russian Far East think tank of Heihe University, project number: 17YDZKCJC04. Title of the project: Russian Far East Evenki Music Studies the production and life of Ewenki people. The songs of early labor production and life derive from hunting and reindeer life. Slogans and shouts are the oldest types of music. Through this ancient method, people and people, and people and nature can exchange harmoniously. For example: "Sled Singing" describes the sleigh's cries and praises. The sled people brought the deer all together and shouted loud "MottMott!" "Or "hum-hum!" The labor songs that describe the hunting and production are often set against the background of steep mountains and dense forests. The labor songs mainly express the good feelings of the Ewenki people hunting in the forest in the production labor.

\section{B. Homesick Folk Songs}

There are many works in the Ewenki folk songs about homesick. The Ewenki people have deep feelings for their hometown. They praise beautiful mountains, vast grassland, cattle and sheep all over the land, and reindeer in the forest in songs. They extol the blossoming spring and the hot summer days, golden autumn, and winter snow. For example: in the song "Golden Yalu River", it expresses the deep feelings of the Ewenki people for their hometown.

\section{Golden Yalu River shines Golden Light}

Waves of Golden Yalu River roll over and over.

The scenery of all things is good.

Here is my hometown that I always miss.

This song deeply expresses the Ewenki people's sense of missing for the Yalu River. This mother river played an important role in the production and life of the Ewenki people.

\section{Love and Wedding Folk Songs}

The theme of human reproduction is love and wedding in the eyes of the Ewenki people, and it is also an important part of the life of the Ewenki people. This kind of song not only contains the Ewenki people's task of choosing the family and reproducing the offspring, but also contains the pursuit of the Ewenki people for truth, kindness and happiness in the life. These feelings are fully reflected in the Ewenki folk songs.

The Ewenki love songs and wedding songs have their own system, including love songs, lost love songs, and wedding songs and so on. These songs convey the love and wedding culture of the Ewenki people in a vivid and 
exaggerated way. For example: "The Wedding Banquet" is a classic that has been sung at the Ewenki wedding.

Good wine in a silver cup

Toast to distinguished guests

For the new couple

Send a forever blessing

Good wine in the golden cup

Toast to distant relatives

Your become husband and wife

Have lifelong love and happiness

When the Ewenki people hold a wedding, the beautiful music melody will be accompanied, and they will dance together happily, gradually bringing the joyful atmosphere of the wedding to a climax.

\section{Historical Folk Songs}

In the long history of the Ewenkis, they experienced a long period of war and migration. It was not until the founding of new China that they were far from the battlefield, but this long and restless historical life was all manifested in the culture of their nation. Today's people can understand and perceive the changes in the thoughts and feelings of the Ewenki people in different periods through the folk songs that reflect one event, and express them in the different tunes and contents of folk songs. For example, "Big Brothers Forced to go to the battle" describes a scene where a young Ewenki man was arrested as a soldier:

The rising sun in the east

Covered by thick fog

My beloved brother

Was forced to be a soldier and is on the journey

The sun in the early morning

Covered by layers of dark clouds

My sincerely beloved brother

Was forced to fight for the emperor

This first folk song is a portrayal of the Solon period in the Qing Dynasty. At that time, the Ewenki people were forced to join the army when they reached the certain age, and then they went through the days of fighting in north and south. The endless wars destroyed people's good lives. People could not talk about love, build a family, and live a happy life. Therefore, there are many Ewenki historical folk songs that are similar to this example. The Ewenki people use folk songs to present history, in order to alert people to cherish the peaceful life, stay away from the war, and continue the miserable life of the war.

\section{E. Divine Songs}

The folk songs related to the Ewenki beliefs are their national divine songs. The main content of the divine songs is related to the Ewenki animism. As a form of expression, the divine song appears in Ewenki people's lives.

Shaman Divine Song is a folk song that relates to Shaman beliefs. Shaman is the messenger of communication between human and God. It plays an important role in the traditional folk songs of the Ewenki people and has a great influence. The Ewenki people believe in nature. They believe that everything in the world has a soul and their souls have their own gods, so people must respect and care for everything. In the shaman belief, there are many divine songs based on belief. In these divine songs, there is their respect for all things in the world, as well as related rituals, but also include shamans for activities such as blessing, marriage and funeral, exorcism and treatment and so on. It can be said that the Ewenki Shaman divine songs was generated during the early hunting period, and has been passed down to today from mouth to mouth.

The faith rally divine songs are the divine songs sung by the shamans in the Ewenki-related rally. There are many rallies believing in Shaman in Ewenki, and they sing divine songs every time they hold the activities. The most grand rally event is one held on 15th April every three years in lunar calendar. During this period, the old shaman of the family leads people to sing divine songs, which is one of the most important activities of the event. The music structure of divine song is relatively simple, and the rhythm changes and fluctuates. According to the plot of music, there are three stages of opening, praying, and inviting God. The music is slow and relaxed at the beginning of the event, then becomes intensely rough when praying, and gradually changes to be relieved.

\section{THE CLASSIFICATION OF THE CREATION GENRES OF EWENKI FOLK SONGS}

The classification of the Ewenki folk songs can be divided according to the music genre or music form into four types: dance music, Nyimahan, Zarndala, and shaman.

\section{A. Dance Music}

The Ewenki is a nation that is good at singing and dancing, and there are many kinds of dance music. At present, there are eight forms of folk dance that can be found. Among them, those are spread in the Ewenk Autonomous Banner include: Anqin Dance (Hunting Dance), Ballenad Dance (Tiger Dance), and Alhambra Dance (dancing or bustle), Nie Naken Dance (Hound Dance), Ganriqie Dance (Swan Dance), in which the hunting dance not only reflects the Ewenki national spirit with distinct hunting culture, but also is the earliest source of its national music. In the Čabar ethnic minority township, there are: Edahara (Wild Boar Fighting Dance), Abud Dance (wishes), Edahara Dance and balenade Dance also reflect ancient hunting life, which can be said to be the living fossil of the Ewenki hunting culture. Ikan dance (bonfire dance) is circulated in the Aoluguya town.

From the perspective of form, the Ewenki dance music (Nukkele) is divided into two types: shouting type and singing type. 
The first category: the shouting type of folk dance music This music is the oldest "noisy music", which has no melody restrictions and the lyrics do not express specific content. The shouting composed of various extra words cannot be expressed by normal lyrics. The shouting has a distinct rhythm, and the dance steps are closely combined with the fixed rhythm to make the dancers move in harmony with the movements.

The second category: the Ewenki dance music is the singing type. The ancient mountain hunting culture greatly influenced the singing type of Ewenki dance music, and the singing type of Ewenki dance music experienced the process of changing from simple to complex.

\section{B. Nimahan}

The Ewenki people called the narrative folk song with the characteristics of rap as Nimahan. People from different regions have different names for this form: "Nimuahan", "Nim Akan" and "Nimakan". It has the characteristics of rap and narrative in performance.

First, Nimahan combines rap and singing. According to the needs of the content, the performer not only has to speak out the content and sing the content, but also need to perform the content. The combination of rap and singing is a more obvious feature, and most of Nimahan is long. The content is also extremely rich, mainly including narrative content such as heroic epics, myths, fairy tales, and long love stories. The freedom of rhythm will also vary due to regionality.

Second is the narrative nature of Nimahan music. Narrative nature is mainly embodied in the ideological content of expression, which not only has the aesthetic connotation but also the characteristics of "grand narrative". The theme is rich, including heroic epics, fairy tale "Dream Words", "Song of the roe deer", long love story "Jinzhu and Zhulie", "The Story of Two Birch Trees", and fairy story "Sven Unaki". The song "Sven Unaki" expresses the thoughts and emotions of the Ewenki people. The Ewenki lived on hunting and reindeer for generations. They migrated several times and finally lived in cold areas. They hunt and train reindeer in the snow and ice every day. For them, the sun is a symbol of warmth, so they have an incomparable admiration for the sun god.

Third, the freedom of rhythm beats. The tone of Nimahan music is the same as that of other ethnic music, which is a five-tone style. The music genre is mostly in the form of Gong tone, Zheng tone, and Yu tone, and transfers the tone in close relationship between the upper and lower five degrees. It has the characteristics of lyricism and narrative, in which the lyricism is more prominent.

Nimahan is the artistic and cultural treasure of the Ewenki people. It not only brings together the rich life story of the Ewenki people, but also cherishes people's yearning for a better life, which is a valuable spiritual food for people. This rap music has a certain appeal and a high artistic and cultural value, conveying the cultural essence of the Ewenki people for thousands of years.

\section{Zahn Dara Yanga}

"Zahn Dara Yanga", also called as "tsandolarga", is the title of folk songs in the Ewenki. It is the generic term of the Ewenki folk songs and minor songs. Its musical characteristics are closely related to the life of the Ewenki people.

- Classification based on music genre It can be divided into two categories: long tune Zahn Dara Yanga and short tune one. The melody of long tune Zahn Dara Yanga, similar to that of the Mongolian long tune Uri Ting, has few lyrics and long tone. The rhythm is slow and free without fixed rhythm, and the singing style is varied. But most of the long tune Zahn Dara Yanga is closely related to the regional style and varies from place to place. The melody of short-tune Zahn Dara Yanga is similar to the Mongolian short tune folk song Bao Guni, with more lyrics, shorter tone and a fixed rhythm.

The "long" and "short" tune of Zahn Dara Yanga are closely related to the living areas and living environment of the Ewenki people. It can be said that the living area and living environment affect the style of Zahn Dara Yanga. The Ewenki people living in the vast grasslands lived on animal husbandry, so they mainly sing the long tune Zahn Dara Yanga. The Ewenki people living in the dense forests mainly sing short tune Zahn Dara Yanga.

- The characteristics of rhythm beat of Zahn Dara Yanga. Zahn Dara Yanga can often transform the tempo, with the three-tempo compound tempo, and the mixed tempo occupying the dominant position of Zahn Dara Yanga. The colorful culture of the Ewenki people has formed the colorful music characteristics of Zahn Dara Yanga.

\section{Shaman Tone}

Shaman tone is a genre of folk songs, which is related to shamanism and sung by shaman. Shaman tone is a religious song that includes three parts: lyrics, melody and dance. The shaman tone has a short structure and varied rhythms, with mysterious color of ancient religion. Through the relationship between shaman and Zahn Dara Yanga, Nimahan, music and dance, it is not difficult to see that the Ewenki primitive religion has a profound influence on the Ewenki music culture.

\section{THE EWENKI MUSICAL INSTRUMENT}

The folk musical instrument of Ewenki is one of the important cultures of this nation and has great research value. The Ewenki performers are good at observing nature, experiencing life, listening to the beautiful sounds of nature, accurately creating all the surrounding sounds and expressing them in the best way.

\section{A. Chur}

It is composed of a body, a fingerboard and a head used for hanging strings, bows and two strings. The body is oval 
and covered with animal skin, and the resonator is above the body. The lower part of the body also has two bridges that hang strings for connecting the strings. The product is installed on the side of the pressing plate. The materials used are wood and horses. Playing Chur has to use the technique of pulling string, which means completing the legato and staccato with the bow.

\section{B. Plucked String Instruments}

Sebudepuchu has the meaning "happy", and it is famous for its distinctive timbre. The tone is sometimes cheerful and sometimes deeply touched. It is composed of body, the fingerboard, and the head used for hanging strings and three strings. The body is covered with deer skin. When playing, players use a flat plastic piece in the right hand to make a sound as medium, and use the same strength to pluck the strings from top to bottom and bottom to top.

\section{Mouth Organ}

The mouth organ is a modern metal instrument but has a long history. In the past it was made of wood and bone. The mouth organ is shaped like a cone, with an elliptical or rounded tail, and a thin steel piece in the middle of the end. The end is 1 to $2 \mathrm{~cm}$ longer than the body. The body is made of iron or brass. When playing, players hold the tail with the left hand, put it between the lips, and push the steel piece with right hand to make a buzzing sound in the mouth. Its sound range is narrow and the pitch is variable. It can imitate the birds without fixed tune. Young men and women play mouth organ while in love, and convey love while playing.

\section{Kongkaer}

Kongkaer is a percussion instrument of the Ewenki. It consists of several percussion instruments, with six highsized small cylinders installed in one direction, and a sound bar and balance sounder installed on a triangular shelf. There are two or four incisions on the pronunciation rod to provide resonance with the instrument. Therefore, the instrument is easy to assemble, disassemble, and elegant in style, which is suitable for performances and beautiful music.

During the performance, different trebles and timbres are played by tapping across the surface of the cylinder. The player needs to learn the dance movements so that they can move around the instrument more flexibly and gracefully. Small differences in the intensity of the attack can be reflected very sensitively. Therefore, flexible wrists and fingers are especially important for playing Kongkaer.

\section{CONCLUSION}

In summary, the music culture of the Ewenki people is mainly discussed from the two parts: vocal music and instrumental music. The Ewenki folk songs are divided into five categories: labor songs, homesick folk songs, love and wedding folk songs, historical folk songs and divine songs. From the creative genre, it is divided into four categories: dance music, Nimahan, Zahn Dara Yanga, and shaman tone; Ewenki instruments include Chur, plucked string instruments, mouth organ, and Kongkaer. This paper traces the Ewenki music culture, interprets the Ewenki music culture and art form, tries to grasp the important value of the Ewenki music culture from the current situation and development prospects of the Ewenki music culture, and provides a reference for the survival and development of China's national music culture, which has certain realistic value.

\section{REFERENCES}

[1] Miao Jinhai. The Construction and Identity of the Ewenki Musical Culture[J]. Journal of the Central Conservatory of Music, 2017.(02). 苗金海. 鄂温克族音乐文化建构与认同 $[\mathrm{J}]$. 中央音乐学院学 报, 2017. (02).

[2] Liang Xueping. Study on the Cultural Dilemma of Ecological Immigrant_ Taking the Aoluguya as an Example[J]. Heilongjiang Nationality Series, 2017.(02). 梁雪萍. 生态移民的文化困境研究一 一以敖鲁古雅使鹿鄂温克民族为例 $[\mathrm{J}]$. 黑龙江民族从 刊, 2017. (02).

[3] Quan Si. Focus on the Evolution of the Living Space of the Ewenki People [J]. Guizhou Ethnic Studies, 2014. (08). 权思. 聚焦鄂温克族 的生存空间嬗变 $[J]$. 贵州民族研究, 2014. (08).

[4] Liu Jianyu. Analysis of the framework of the Ewenki national culture communication under the new media environment [D]. Inner Mongolia University, 2017. 刘建余. 新媒体环境下鄂温克族民族文 化传播的框架分析 [D]. 内蒙古大学硕士学位论文, 2017. 